\title{
O DRAMA HISTÓRICO LATINO E SUAS PROJEÇÕES NO MUNDO RENASCENTISTA E BARROCO
}

\author{
ZELIA DE ALMEIDA CARDOSO* \\ Faculdade de Filosofia, Letras e Ciências Humanas \\ Universidade de São Paulo
}

\begin{abstract}
RESUMO: Assim como aconteceu com a tragédia e a comédia antigas, que ressuscitaram durante o Renascimento e o período barroco, o drama histórico de assunto romano - herdeiro da pretexta latina - também voltou a ser explorado por teatrólogos do momento. Na Itália, na França, na Inglaterra e na Espanha, começaram a surgir, nos séculos XVI e XVII, dezenas de peças focalizando a história de Roma, peças que fizeram sucesso e prepararam, de alguma forma, a eclosão, nos séculos XIX e XX, do romance "romano" e do peplum - o filme cinematográfico que pôs em evidência fatos que marcaram a importância da Cidade Eterna.
\end{abstract}

PALAVRAS-CHAVE: Renascimento; periodo barroco; drama histórico; pretexta; peplum.

\section{Introdução}

O estudo da história do teatro nos mostra que, assim como ocorreu com outros gêneros dramáticos, a tragédia de assunto histórico também se revitalizou no mundo ocidental durante o Renascimento e o período barroco. E é interessante verificar que entre os argumentos escolhidos pelos novos dramaturgos os que foram extraídos da história de Roma ocuparam lugar de destaque. $\mathrm{O}$ fenômeno corresponde, portanto, a uma espécie de ressurreição da tragédia pretexta, ${ }^{1}$ modalidade teatral tipicamente romana, cujo assunto corresponde à exploração de acontecimentos supostamente reais.

As tragédias e comédias latinas, baseadas no teatro grego, começaram a ser compostas e representadas em Roma em meados do século III a.C. Os primeiros tragediógrafos, embora se tivessem dedicado predominantemente à elaboração de peças mitológicas, inspiradas sobretudo nas de Eurípides, compuseram também tragédias pretextas, valendo-se, na composição dos enredos dramáticos, de fatos 
de importância histórica realmente ocorridos em Roma ou admitidos como verídicos. ${ }^{2}$ Névio (?-201 a.C) e Ênio (239-169 a.C.) escreveram as primeiras pretextas de que se tem notícia. Névio, com Clastídio (Clastidium) e Rômulo (Romulus), foi o verdadeiro criador do gênero; Ênio seguiu-lhe os passos, compondo As Sabinas (Sabinae) e Ambrácia (Ambracia). ${ }^{3}$ Foram delineados, com esses textos, os dois caminhos que seriam tomados pela pretexta: a exploração de velhas lendas históricas preservadas possivelmente em canções - é o caso de Rômulo e de As Sabinas ${ }^{4}$ - e a abordagem de temas contemporâneos, de importância política - é o caso de Clastídio e de Ambrácia. ${ }^{5}$

No período helenístico foram ainda escritas algumas outras pretextas: Pacúvio (220-130 a.C.) compôs Paulo (Paulus); Ácio (170-86 a.C) escreveu Décio (Decius) e Bruto (Brutus). ${ }^{6}$

Pouco restou dessas tragédias; apenas alguns versos esparsos foram citados por escritores posteriores. Das pretextas latinas, a única que se preservou como obra completa foi Otávia (Octauia), tragédia tardia, composta provavelmente no final do século I de nossa era e considerada por vezes como uma obra de Sêneca. Essa pretexta não é uma peça comemorativa de triunfos ou referente a antigüidades romanas, como as anteriores; focaliza o repúdio e o exílio de Otávia, a primeira esposa de Nero, e aponta, portanto, para outra possibilidade de argumento do drama histórico latino: a exploração de problemas políticos ou doméstico-políticos.

O texto de Otávia chegou à posteridade em um manuscrito que continha as tragédias senequianas ${ }^{7}$ - daí o fato de sua autoria ter sido atribuída ao tragediógrafo cordovês - por ser a única pretexta supérstite representa uma espécie de ponto de partida de toda uma produção dramática que se ocupa da história romana e começa a reflorescer durante o Renascimento. Ao lado das tragédias e comédias, baseadas na temática antiga e substitutivas dos "milagres", "mistérios", "moralidades" e farsas medievais, esses dramas históricos que se voltam para a Antigüidade e exploram fatos da história romana correspondem a uma redescoberta da pretexta, que retorna aos palcos quinhentistas e seiscentistas sob vestimentas novas.

Na Itália de Trissino e Aretino, na França de Jodelle, Garnier, Corneille e Racine, na Inglaterra de Shakespeare, Jonson e Massinger, na Espanha de Cervantes, a tragédia de assunto romano ressuscita, ombreando com textos trágicos que focalizam a história moderna ou que se detêm na exploração de temas mitológicos, bíblicos ou romanescos. Os argumentos romanos utilizados pelos teatrólogos desse período cobrem toda a história de Roma, da época dos reis ao baixo império. Os enredos das peças envolvem inúmeras figuras históricas ou pseudo-históricas, per- 
sonagens romanas como os Horácios, Lucrécia, Virgínia, Coriolano, Cipião, Catão, Cornélia, Mário, Sula, Pompeu, Júlio César, Marco Antônio, Otávio, Cícero, Lívia, Cina, Sílio, Agripina, Nero, Britânico, Oto, Tito, Teodósio, Pulquéria, e personagens estrangeiras, vinculadas de alguma forma à história de Roma, quer na condição de aliadas quer na de inimigas; é o caso de figuras tais como os Curiácios, Massinissa, Sofonisba, Aníbal, Viriato, Surena, Nicomedes, Cleópatra, Mitridates, Átila, Berenice.

No presente estudo pretendemos fazer um primeiro levantamento das peças baseadas na história de Roma compostas nos séculos XVI e XVII, focalizando o percurso dos temas "romanos" na obra de arte teatral. Esses temas vêm da Antigüidade; atravessam a Idade Média, reaparecendo em alguns dos "milagres" que exploram a história dos mártires cristãos, e florescem durante o Renascimento e o período barroco, abordados pelos principais dramaturgos da época. Não se limitam, no entanto, a essa época de encantamento e redescoberta dos clássicos: permanecem, de alguma forma, nos séculos XVIII e XIX, exercendo influência sobre o romance nascente, e se fazem presentes não só no romance e no teatro do século $\mathrm{XX}$, quando grandes teatrólogos como Bernard Shaw ou Albert Camus, compõem obras da importância de um César e Cleópatra ou de um Calígula, mas também na cinematografia, ${ }^{8}$ que corresponde a um prolongamento do teatro.

O presente estudo, entretanto, se restringe aos séculos XVI e XVII, quando foram compostas alguma das principais tragédias históricas de assunto romano da era moderna.

\section{Temas romanos na tragédia italiana}

Pouco restou do teatro medieval italiano. Durante o Quattrocento, o teatro de inspiração religiosa, a chamada Sacra Reppresentazione, passou por uma profunda transformação, enriquecendo-se com cenas cômicas e populares que prenunciavam o triunfo do teatro profano com a commedia dell'arte e a pastoral. Na segunda metade do século XV começam a ser representadas traduções de comédias de Plauto e de tragédias de Sêneca em "língua vulgar", bem como obras teatrais da época, inspiradas nas peças latinas e escritas em latim. A total reformulação do teatro só vai ocorrer, entretanto, no início do Cinquecento, com a primeira comédia de Ariosto, Cassaria (1508), e a primeira tragédia de Trissino, Sofonisba (1515).

Giangiorgio Trissino (1478-1550) inaugura com Sofonisba uma nova forma do fazer dramático. Processavam-se, no mundo artístico, profundas e radicais trans- 
formações. A Itália começava a tomar contato com os tragediógrafos gregos; a Poética de Aristóteles voltava a ser estudada e discutida; crescia o desejo de oferecer-se ao homem do Cinquecento uma tragédia moderna escrita em volgare e construída nos moldes gregos. Sofonisba representa a concretização dessa intenção. Curiosamente, essa primeira tragédia extrai seu argumento da história romana, tendo traços comuns, portanto, com as antigas pretextas latinas. Sofonisba, a personagem-título, era uma rainha cartaginesa, é certo, mas somente conhecemos seu destino trágico, determinado pelo poder romano, porque as mais antigas informações históricas sobre ela foram fornecidas por Tito Lívio nos livros XXVIII e XXX de sua História Romana (Ab Vrbe condita). Segundo o historiador, a rainha era filha de Asdrúbal e se casara com Sífax, rei da Numídia. Por influência da esposa, Sífax não fizera aliança com Roma durante a segunda guerra púnica, e, em conseqüência dessa atitude, foram ambos aprisionados pelo príncipe númida Massinissa, aliado dos romanos. Massinissa pretendia fazer de Sofonisba uma concubina, mas Cipião, o Africano, temeroso da influência que a bela mulher poderia exercer sobre o aliado, tomou a decisão de levá-la a Roma como escrava. Massinissa, numa espécie de represália, enviou um veneno à rainha prisioneira com o qual ela se suicidou. $O$ fato histórico se presta, pois, a um tratamento dramático. ${ }^{9}$

A tragédia de Trissino segue de perto o relato liviano mas se ressente de certa frieza e as personagens são construídas sem o vigor necessário e sem a preocupação com os contrastes: parecem meros pretextos para ilustrar algumas das antigas regras dramáticas. Embora Trissino tenha suprimido a divisão em atos, o coro é restabelecido, em sua função de personagem coletiva; as lamentações são abundantes; a ansiedade trágica é abafada pelas digressões morais nas quais se inserem sentenças filosóficas genéricas, interrompidas freqüentemente pelo uso de esticomítia; os diálogos, a exemplo do que se estabelece entre Lélio e Cipião, quando se discute o destino da rainha, são longos e enfadonhos. A linguagem, conforme a opinião de Vicinelli (Vicinelli, s/d, p. 338), é "rasteira, monótona e destituída de poesia”. ${ }^{10}$

Referindo-se a Sofonisba, Giuseppe Toffanin (Toffanin, 1935, p. 450) é de opinião que Trissino não conseguiu apreender o "espírito da tragédia grega", ao transpor o mito para a história. Além do mais, para ele, os versos de Trissino são "rígidos e opacos" e o texto é monótono. Não se pode negar, contudo, ao teatrólogo, o mérito de abrir novo caminho para a dramaturgia num mundo que se renovava culturalmente. Embora a postura de Trissino tenha sido bastante polêmica no que diz respeito à valorização dos cânones gregos na tragédia, a importância de sua 
obra é indiscutível pelas mutações que provocará na literatura dramática posterior (Squanotti, 1989, p. 258). Alguns teatrólogos italianos seguirão suas idéias, a exemplo de Giovanni Rucelai, Sperone Speroni e Pietro Aretino; outros, como Giambattista Giraldi Cinzio, se oporão a ele, levando a tragédia renascentista para outra direção.

Fazendo frente à tragédia grecizante e moralista de Trissino, Giambattista Giraldi Cinzio (1504-1573) defendeu a imitação das tragédias de Sêneca, a divisão em atos, a liberdade no emprego do fantástico, as cenas cruas e macabras e o estilo ornamentado, que conduz à declamação enfática. Não só publicou a esse respeito um texto teórico e crítico, o Discorso intorno al comporre delle tragedie, como escreveu Orbecche (1541), sua peça mais famosa, e algumas outras tragédias, procurando ilustrar seu ponto de vista. É curioso, porém, que, embora defendesse o uso de uma temática nova nas peças trágicas, Cinzio se tenha baseado em fatos da história romana ao escrever Cleopatra, por volta de 1545. É mais um exemplo da influência exercida pelos fatos antigos sobre a imaginação de um teatrólogo do século XVI.

Dos seguidores de Trissino, Rucelai e Speroni se dedicaram, respectivamente, a temas medievais e mitológicos; Aretino retornou à história romana, ao compor a tragédia Orazia (1546).

Segundo Vicinelli (Vicinelli, s/d, p.338), somente a "frieza psicológica e expressiva" das peças de Trissino, Rucelai e Speroni faz Orazia parecer "mais calorosa e viva", justificando a acolhida crítica que lhe foi feita. Para ele, a tragédia de Aretino, que se inspira na história da luta entre Horácios e Curiácios, relatada por Tito Lívio (XXVIII-XXX), ${ }^{11}$ apresenta as mesmas características das que lhe são contemporâneas: são obras mais literárias do que propriamente dramáticas, faltando-lhes movimento e ação, o que talvez tenha determinado o fato de só terem sido representadas muito depois de haverem sido escritas.

No século XVII o tema romano aparece em uma ópera de Claudio Monteverdi (1567-1643), um dos primeiros compositores do bel-canto. Após ter feito sucesso com peças inspiradas na mitologia grega e em temas medievais, Monteverdi compôs L'Incoronazione di Poppea, com libreto de G. Francesco Busenello, considerado como um dos grandes libretistas da época. Última ópera do compositor, escrita quando ele já tinha 75 anos, L'Incoronazione di Poppea é considerada por muitos sua verdadeira obra-prima. A ópera se inspira na pretexta Otávia e explora a história de amor de Nero e Popéia, pondo em relevo o exílio da esposa repudiada e a coroação da nova imperatriz. 


\section{Temas romanos na tragédia francesa: os precursores de Corneille}

Como ocorreu na Itália e em outros países da Europa ocidental, na França renascentista, a partir da segunda metade do século XVI, houve também profundas transformações no teatro. Até então, embora nos outros gêneros literários já se sentisse um ar de renovação, os textos dramáticos ainda se deixavam influenciar pelo espírito medieval. "Mistérios", farsas, soties e "moralidades" continuavam sendo representados, ${ }^{12}$ mas, ao mesmo tempo, enquanto tragédias e comédias gregas e latinas começavam a ser traduzidas ${ }^{13}$ e encenadas, alguns escritores, como George Buchanan (1506-1582), escossês que viveu na França por algum tempo, e MarcAntoine Muret (1526-1585), também conhecido como Marcus Antonius Muretus, escreviam tragédias em latim.

De Muret interessa-nos sua tragédia Julius Caesar, escrita em 1544, quando o autor tinha apenas 18 anos. É uma peça curta, composta de cerca de 600 versos, própria para ser representada por colegiais, em suas experiências acadêmico-dramáticas. Bastante influenciada pelas tragédias de Sêneca e pela Otávia pseudosenequiana, Julius Caesar se compõe de cinco atos intercalados por cânticos corais e apresenta alguns recursos dramáticos que haviam sido utilizados com freqüência pelo escritor latino: longos monólogos, tiradas filosóficas, aparições de espíritos de mortos, referências a sonhos proféticos. $\mathrm{O}$ argumento da tragédia de Muret é muito semelhante ao que vai aparecer mais tarde na peça homônima de Shakespeare: César vive no auge de sua glória política, em que pese a "inconstância da fortuna"; Bruto está praticamente convencido de que César se tornou tirano e se associa a Cássio numa conspiração; Calpúrnia sonha com César morto e tenta convencer o marido a não sair de casa nos idos de março; César não a atende, é morto pelos conspiradores e a voz de seu espírito procura consolar a esposa em lágrimas. A peça de Muret mereceu elogios de Buchanan e dos participantes da Pléiade. ${ }^{14}$

A tragédia e a comédia propriamente francesas, entretanto, só vão surgir alguns anos depois, em 1552, quando Etienne Jodelle (1532-1573), muito jovem ainda, compõe Cléopâtre (depois chamada Cléopâtre captive) e Eugène. ${ }^{15}$ Interessanos Cléopâtre, cuja produção foi recebida com entusiasmo por Ronsard. Instiganos o fato de a primeira tragédia francesa, como ocorreu com a primeira tragédia italiana, apresentar um tema extraído da história romana. Hoje, a peça de Jodelle pode parecer um pouco lenta, com sua ação arrastada e com as longas lamentações que se alternam com cânticos corais não menos prolongados, ${ }^{16}$ o que faz com que já tenha sido considerada mais como um "drama lírico" do que propriamente como tragédia. Petit de Julleville (Julleville, 1927, p. 76), apesar de julgá-la fria e 
desinteressante, não deixa de observar os méritos que tem: o número reduzido de personagens, em contraposição com os "mistérios" medievais, a simplicidade da ação, a observância das unidades dramáticas, o estilo nobre, a novidade na escolha do assunto. Com sua tragédia, Jodelle proporciona uma nova direção ao teatro francês, marcando de forma significativa a ruptura com a tradição medieval. ${ }^{17}$

Em 1558, os Confrères de la Passion representam César (ou Mort de César), tragédia de Jacques Grévin (1538-1570), discípulo de Ronsard, inspirada no Julius Caesar, de Muret. Influenciada pela tragédia de Sêneca - como o haviam sido as de Muret e Jodelle -, a peça de Grévin, em que pesasse a juventude do autor, ${ }^{18}$ revela maturidade, capacidade de trabalho e perspicácia na utilização de procedimentos teatrais Com abundância de situações dramáticas e versos oratórios, é mais uma herança da pretexta latina.

Nas últimas décadas do século XVI, quando Scaligero já havia publicado uma Poética, em latim, estabelecendo as regras das unidades de tempo e de ação na tragédia - regras que serão ampliadas por Jean de la Taille, em Art de la Tragédie (1572) -, Robert Garnier (1544-1590) faz suas primeiras incursões pela dramaturgia e oferece ao público as tragédias Porcie (1568), Hippolyte (1573), Cornélie (1573), Marc-Antoine (1578), La Troade (1578), Antigone (1578) e Les Juives (1580) e a tragicomédia Bradamante (1580), peça com a qual inaugura o novo gênero. Porcie, Cornélie e Marc-Antoine têm enredos extraídos da história romana e se ressentem de profunda influência da obra de Sêneca. Em Porcie, por exemplo, texto que explora a desgraça da filha de Catão que se tornara esposa de Bruto, o prólogo é recitado por Megera, uma das Fúrias, procedimento semelhante ao que se pode observar no Thyestes senequiano; o coro, composto de mulheres romanas, faz várias intervenções, valendo-se da temática dos coros de Sêneca: ora deplora a instabilidade da Fortuna, ora canta as delícias da vida campestre, ora se compraz em prolongadas lamentações. O final violento, marcado pelo suicídio de Pórcia, que engole carvões em brasa, e pelo da ama que se apunhala em solidariedade com sua filha de criação, tem muito dos finais do dramaturgo cordovês. Até mesmo a exortação a Otávio feita pelo filósofo Areu, que aconselha o jovem guerreiro a agir com clemência, pode ser considerada como reminiscência de Sêneca. ${ }^{19}$

Em Cornélie, Garnier explora os conflitos da filha de Cipião que se tornara esposa de Pompeu, bem como suas lembranças e expectativas. Merecem nota o monólogo de Cícero, no primeiro ato, com reflexões sobre a sede de conquistas, o diálogo entre Cícero e Cornélia, no segundo ato, quando ela atribui sua desgraça ao fato de ter-se casado uma segunda vez, as lamentações da mulher, no terceiro 
ato, no momento em que ela recebe a urna com as cinzas do pai, e o relato do mensageiro, no êxodo, envolvendo a descrição da batalha final de que participou Cipião. Em Marc Antoine, caracterizada pela presença de longos monólogos, explora-se o curto período que medeia entre a derrota do herói em Ácio e o suicídio de Cleópatra. É mais uma peça marcada pela influência de Sêneca e mais uma herança da pretexta latina.

Referindo-se a essas obras de Garnier, Julleville, embora o julgue um verdadeiro poeta, dotado de grande imaginação, capaz de compor belas narrações e coros líricos variados, dada a profusão de metros empregados, considera-as mais como "elegias dialogadas" mescladas a trechos declamatórios do que como tragédias propriamente ditas já que carecem de uma ação dramática bem estabelecida (Juleville, 1927, p. 79 s.). Para ele apenas em Marc-Antoine a ação tem um desenvolvimento mais cuidado.

Alguns outros teatrólogos franceses se valeram de temas "romanos" em suas tragédias entre o final do século XVI e o momento em que Corneille, em 1640, compõe Horace, a primeira "pretexta" francesa de real importância: Antoine de Montchrestien, Alexandre Hardy, Jean de Mairet, La Calprenède, Scudéry, Du Ryer, Bensérade, Desmarets de Saint-Sorlin.

Antoine de Montchrestien (1575-1621) é o autor de mais uma Sophonisbe, sua única tragédia com tema filiado à história romana, em meio a outras com assunto histórico, mitológico ou bíblico. ${ }^{20}$ Ao escrevê-la o autor retoma o episódio da morte da rainha da Numídia, que já fora tratado por Trissino e que será explorado outras vezes mais, por numerosos dramaturgos. As peças de Montchrestien são muito diferentes umas das outras pelo temário, mas semelhantes nos procedimentos dramáticos e no estilo a um tempo leve e vigoroso. Líricas e eloqüentes, ressentem-se, no entanto, como as tragédias de Garnier, de certa falta de ação.

Alexandre Hardy (1560?-1620), considerado por vezes como verdadeira "máquina de produzir textos teatrais", compôs, de 1595 a 1620, cerca de 600 peças, aí contadas traduções, adaptações e obras originais. Talentoso, espirituoso, imaginativo e dotado de imensa capacidade de trabalho, escreveu além de tragicomédias e pastorais, que contribuíram para a consolidação dos dois subgêneros, tragédias cujo tema se prende à lenda mitológica ${ }^{21}$ e três peças cujo assunto se baseia na história romana: Coriolan (1600?), Cornélie (1609) e Lucrèce (1616). Apesar dos numerosos defeitos de que seus textos se ressentem - monólogos extremamente longos, conversas intermináveis, coros inúteis para o desenvolvimento da ação, violência barroca mesclada ao espírito humanístico -, Alexandre Hardy tem uma qualidade: 
um verdadeiro "instinto dramático" que o faz descobrir efeitos teatrais interessantes e criar situações originais e de grande densidade (Julleville, 1927, p. 100).

Jean de Mairet (1604-1686), contemporâneo de Corneille, escreveu, entre outras obras, as tragédias "romanas" Sophonisbe (1629) e Marc-Antoine (1630). Embora não sejam excepcionais e retomem assuntos já explorados anteriormente, os textos são dramáticos e comoventes e apresentam os traços essenciais do gênero: nobreza de estilo, eliminação de qualquer vestígio de comicidade, refinamento na análise e na expressão dos sentimentos, simplificação da intriga.

Bensérade (1612-1691), La Calprenède (1610-1663), Scudéry (1601-1667), Du Ryer (!605-1658) e Desmarets de Saint-Sorlin (1595-1676), autores de tragédias históricas de tema romano, foram figuras menores. Bensérade apresentou Cléopâtre, em 1635, uma tragédia de sucesso duvidoso; Scudéry escreveu, em 1636, La mort de César; Du Ryer compôs Lucrèce, também em 1636, e Scévole, em 1646; La Calprenède publicou La mort de Mithridate, em 1637; Desmarets, protegido de Richelieu, levou à cena, por volta de 1639, uma tragédia histórica que não fez grande sucesso, Scipion.

Estava preparado o terreno para as tragédias romanas de Corneille. As "regras das unidades", empregadas por Jodelle e teorizadas por Scaligero e Jean de la Taille, no século XVI, haviam sido reconsolidadas por Mairet, ${ }^{22} \mathrm{em}$ Sophonisbe. De acordo com essas regras as tragédias deveriam respeitar tanto a unidade de ação, representada pela presença de uma intriga única e sem episódios paralelos, como as unidades de tempo e de lugar: a ação deveria desenrolar-se num único dia, num espaço de tempo próximo ao da representação e num único cenário. Deveriam também apresentar "unidade de tom", o que eliminaria a possibilidade de inserção de elementos cômicos ou vulgares, e bienséance ou decorum, ou seja, respeito às regras de conveniência, e verossimilhança. Para atender a essas regras, cenas violentas ou chocantes, cenas de morte, duelos e derramamento de sangue, deveriam ser rigorosamente evitadas e substituídas por relatos de testemunhas ou de mensageiros. Para atenuar a monotonia que poderia caracterizar esses relatos, os tragediógrafos adotaram a praxe de cuidar carinhosamente desses trechos, praticamente carentes de dramaticidade.

\section{As tragédias "romanas" de Corneille}

Iniciando-se no teatro em 1629, ${ }^{23}$ aos 23 anos, Pierre Corneille (1606-1684), somente enveredou pelo campo da tragédia histórica de tema romano em 1640, ao 
compor Horace. Escreveu depois mais treze peças que podem ser consideradas como heranças da pretexta latina: Cinna (1642), Polyeucte (1642), La mort de Pompée (1643), Théodore (1646), Héraclius (1647), Nicomède (1651), Sertorius (1662), Sophonisbe (1663), Othon (1664), Attila (1667), Tite et Bérénice (1670), Pulchérie (1672) e Suréna (1674).

Horace e Cinna, são as mais importantes. A primeira explora a mesma lenda histórica da época dos reis, relatada por Tito Lívio e tratada dramaticamente por Pietro Aretino, na Itália, quase um século antes: a luta entre os Horácios e os Curiácios, que substituiu a batalha que deveria ocorrer entre Roma e Alba. É possível que Corneille, para escrever Horace, tenha utilizado, além da História Romana, outras fontes, de caráter secundário, tais como As Antigüidades Romanas, de Dionísio de Halicarnasso, a Orazia, de Aretino, ou o Honrado Hermano, de Lope de Vega. Mas não só não se pode comprovar rigorosamente essas hipóteses como também é indiscutível que a fonte essencial é o relato de Tito Lívio com o qual a tragédia mantém interessante "diálogo".

Por apresentar conteúdo significativo adequado à dramatização e por contar com elementos altamente "dramáticos", o relato se prestou muito bem como matéria-prima para a tragédia. $\mathrm{O}$ dramaturgo, porém, muito embora tivesse conservado as linhas mestras que a definem, não se ateve apenas à narrativa liviana, dando asas à própria imaginação. De um lado reduziu os figurantes, mantendo no corpo da tragédia somente dois dos jovens guerreiros - um Horácio e um Curiácio - e transformando os demais em personagens existentes mas ausentes do texto dramático; de outro, acrescentou novos elementos conflituosos a uma história que já apresentava um conflito básico de grande porte, determinado pelo fato de uma das irmãs dos Horácios ter sido prometida em casamento a um dos Curiácios: Corneille duplicou o conflito, mantendo o laço afetivo que ligava a um dos inimigos a irmã dos Horácios, à qual deu o nome de Camila (Camille), e introduzindo um novo laço com a criação da figura de Sabina (Sabine), irmã dos Curiácios e esposa de um dos Horácios. Além disso, criou outros conflitos: transformou Valério - que em Tito Lívio é apenas um fecial, ou seja, o membro de um colégio encarregado de observar o direito internacional - num jovem admirador de Camila, rival, portanto, do Curiácio, e introduziu um fato novo na "fuga"de Horácio, fazendo com que o velho pai dos guerreiros romanos recebesse a informação de que o filho fugira do campo de luta por covardia, o que lhe despertou uma ira violenta, materializada na maldição que lançou contra o jovem, ira que só se extinguiu quando a plena verdade veio à tona e a "fuga" passou a ser vista como estratégia de guerra. Com essas modificações, Corneille compôs a "sua" história, enriquecendo, de certa forma, o relato de Tito Lívio. 
Em Cinna, o teatrólogo desenvolveu um fato mencionado no De clementia, de Sêneca: o perdão concedido por Augusto a um inimigo que conspirava contra ele. Bem sucedida diante do público e da crítica, Cinna, segundo as palavras de Pascal Reix (Corneille, 1993, p. 5), une à grandeza de um argumento trágico a presença de "personagens dilaceradas entre o amor e a honra, o perdão e o castigo, a tirania e a democracia", "realizando a alquimia sutil de um teatro em que se mesclam a retórica política e o discurso amoroso, em que o individualismo heróico encontra ao mesmo tempo seu limite e seu término no reconhecimento da grandeza do Estado".

A passagem do De clementia (Cl. I, 9) que forneceu a Corneille o argumento da tragédia foi traduzida por Montaigne em seus Ensaios (I, 23) e apresentada pelo tragediógrafo no prefácio da primeira edição de Cinna. Em seu ensaio, dedicado a Nero, Sêneca relatara um episódio histórico para ilustrar suas considerações sobre a clemência: Augusto se encontrava na Gália quando foi informado de que Lúcio Cina estava chefiando uma conspiração contra ele; disposto a punir o conspirador, convocou um conselho de amigos que deveria realizar-se no dia seguinte; na noite anterior, porém, o imperador se deixou tomar por grande angústia, ao pensar na punição do jovem, e foi aconselhado por sua esposa Lívia a perdoá-lo; Augusto convocou-o então para uma entrevista, disse-lhe tudo o que sabia, perguntou-lhe sobre as razões e possíveis conseqüências da conspiração e o perdoou; após esse ato de clemência Cina e Augusto se tornaram grandes amigos e nunca mais houve outra conspiração contra o imperador.

Muito embora outros historiadores se tenham ocupado do assunto explorado por Corneille, ${ }^{24}$ o teatrólogo segue de perto o texto de Sêneca. Há inovações, é certo, e procedimentos dramáticos especiais. Corneille condensa a ação para subordiná-la às unidades dramáticas de praxe; cria a figura de Emília, a amada de Cina, fazendo-a filha de Torânio, antigo tutor de Otávio, bem como as do conspirador Máximo, dos libertos e das confidentes, atribuindo a cada um uma função específica no desenrolar da ação e uma participação especial nos conflitos; trabalha, pois, com idéias próprias de sua época, no tocante a concepções sobre poder, tirania e lealdade. $O$ texto de Sêneca, no entanto, subjaz ao da tragédia e a influencia poderosamente, proporcionando interessantes momentos para o estudo da intertextualidade. O solilóquio de Augusto, no tratado de Sêneca, está presente em Cinna, revelando a aflitiva angústia do imperador ante o dilema que se lhe apresenta; as palavras de Lívia, em De clementia, são repetidas em Cinna; o diálogo que se trava entre Augusto e o conspirador é reproduzido até em pormenores.

As demais tragédias romanas compostas por Corneille apresentam qualidades, mas são inferiores às duas primeiras. Polyeucte versa sobre a história de um 
oficial convertido ao cristianismo e martirizado por volta de 250 por ter destruído as estátuas de um templo pagão. Lembra, de certa forma, os "mistérios" medievais por retratar a personalidade de um santo, cuja grandeza ombreia com a dos heróis das tragédias precedentes, e tem o mérito de apresentar, entre as personagens, a figura de Paulina, a esposa do mártir, construída com grande delicadeza e vigor. La mort de Pompée, inspirada na Farsália, de Lucano, apresenta fatos que se sucederam à morte do grande general romano, tais como a relação que se estabelece entre César e Cleópatra. Apesar de a linguagem ser por vezes excessivamente enfática, há momentos de sublimidade como os que contam com a presença de Cornélia, viúva de Pompeu. Théodore, tragédia cristã chocante e pouco interessante, segundo a opinião de Julleville (Julleville, 1927, p. 118), tem por assunto a morte do imperador bizantino Teodoro. É uma das tragédias de Corneille menos bem sucedidas. Não chegou a entusiasmar o público nem mesmo quando foi representada pelas primeiras vezes. Héraclius também se inspira na história de Bizâncio, mas diferentemente de Théodore, foi muito bem aceita em sua época. Nela se apresenta a figura de Heráclio, filho do imperador Maurício, ocultado por sua mãe quando o imperador foi morto pelo usurpador Focas. A peça é interessante, apesar de ter uma intriga complicada, decorrente de troca de identidade de personagens, e foi imitada por Calderón de la Barca. Nicomède se volta para uma época bem mais remota e explora a história de Nicomedes, príncipe de Pérgamo e irmão de Átalo, perseguido por Flamínio, o legado romano junto ao reino oriental. A intriga complexa e a presença de personagens risíveis faz com que a peça não seja considerada uma tragédia pura e prenuncie o drama histórico romântico. Sertorius se inspira na história do general romano rebelde que se estabeleceu na Espanha e foi morto por um de seus subordinados, Perpena. A peça fez enorme sucesso, talvez por apresentar algumas cenas de forte dramaticidade, como por exemplo a do diálogo travado entre Sertório e Pompeu. Sophonisbe retoma o mesmo tema já bastante explorado anteriormente: a história da morte da rainha da Numídia que se envenenou para não cair nas mãos dos romanos. Escrita provavelmente para operar como um confronto com a tragédia homônima de Mairet, representada no ano anterior, não chegou a impressionar o público. Othon, baseada em relato de Tácito, explora a história do imperador Oto que, sucedendo a Galba, foi vencido pelas legiões de Vitélio em 69 de nossa era. Attila, cujo motivo central é a derrota do chefe huno pelo general romano Aécio e pelo visigodo Teodorico, é uma tragédia que conta com cenas vigorosas e com um estilo extremamente bem cuidado. Tite et Bérénice tem como tema a desgraça de Berenice, princesa oriental levada a Roma pelo imperador Tito. A história da composição da peça é curiosa. Em 1670, Henriette 
d'Angleterre, duquesa de Orléans, propôs a Corneille e a Racine, que alguns anos antes havia feito a sua estréia como poeta trágico, que escrevessem sobre o mesmo assunto: a separação de Tito e Berenice. As tragédias foram representadas com intervalo de apenas alguns dias e a duquesa não chegou a assistir às representações; nunca se duvidou, porém, de que a Bérénice de Racine é muito superior a Tite et Bérénice de Corneille.

Pulchérie e Suréna são as últimas obras de Corneille baseadas na história romana e passaram praticamente despercebidas. Pulchérie não é uma tragédia e, sim, uma "comédia heróica" de tema romano, cujo assunto é a história da imperatriz de Constantinopla que assumiu o poder em 450, após a morte de Teodósio. Suréna tem por argumento a atuação bélica do general parto que venceu Crasso no fim do período republicano.

Durante os anos em que se ocupou com a dramatização de temas romanos, Corneille escreveu também comédias, ${ }^{25}$ tragédias de assunto histórico não romano, ${ }^{26}$ tragédias mitológicas ${ }^{27}$ e uma peça para teatro de máquinas. ${ }^{28}$ As qualidades do dramaturgo são indiscutíveis. Segundo Lagarde e Michard (Lagarde \& Michard, 1958, p.106), "nenhum outro autor dramático aprofundou a essência de sua arte e meditou sobre os problemas por ela suscitados com o rigor e o escrúpulo de Corneille". Para o teatrólogo - e isso pode ser depreendido dos textos teóricos que escreveu -, o assunto das tragédias deve ser extraído de um episódio célebre da história ou da lenda, fato que elimina a possibilidade de intrigas inventadas; a ação deve ser grandiosa; as personagens, ilustres e nobres.

As intrigas das tragédias de Corneille são muitas vezes complexas e até sobrecarregadas, ricas em peripécias e efeitos cênicos. É o que se pode observar em Héraclius, por exemplo. O tom político desempenha freqüentemente importante papel nas tragédias cornelianas: em Horace há uma preocupação constante com a vitória de Roma; em Cinna, discute-se a questão do poder; em Nicomède, o herói se insurge contra Roma. Por outro lado, o amor também tem sua função bem delineada. $\mathrm{O}$ "conflito trágico" nasce muitas vezes dos confrontos entre os sentimentos e o dever.

Os caracteres, bem compostos, são bastante diversificados: enquanto Cleópatra é uma figura monstruosa, Polyeucte é um santo, Horácio nos causa horror ao matar a própria irmã e Augusto encarna em si todas as qualidades de um soberano justo e clemente. A psicologia e a moral de Corneille são otimistas por valorizarem a grandeza e a liberdade do homem, sua capacidade em fazer as paixões grandiosas triunfarem e em conduzir o próprio destino. A morte não é apresentada como uma desgraça ou um desastre e, sim, como algo que exalta o próprio herói. 


\section{As tragédias "romanas" de Racine e de seus contemporâneos}

Durante os quarenta e três anos em que Corneille se dedicou ao teatro, vários outros dramaturgos franceses compuseram tragédias e, entre elas, peças históricas que abordam temas romanos. É o caso de Tristam l'Hermite, por exemplo, de Rotrou e do próprio Racine, considerado, ao lado de Corneille, como o grande representante da tragédia francesa do século XVII.

Tristam l'Hermite (1601-1655) escreveu suas duas peças romanas, La mort de Sénèque e La mort de Crispe ou les malheurs domestiques du grand Constantin, em 1645, depois de ter composto outras peças teatrais. ${ }^{29}$ É um dramaturgo a quem não falta espírito e originalidade, faltando-lhe, porém, um pouco mais de alento e, talvez, de auto-confiança (Julleville, 1927, p. 137).

Rotrou (1609-1650) compôs trinta e seis peças teatrais entre 1628 e 1650, aí contadas comédias, tragicomédias e tragédias. Entre estas há apenas uma de tema romano, Saint Genest, escrita em 1646 e considerada por Julleville (Julleville, 1927, p. 132) como a criação mais original do autor, embora se inspire em Lope de Vega e se ressinta da influência do Polyeucte de Corneille. Nela se explora a história de um ator que, ao representar o papel de um mártir, perante Diocleciano e Maximiano, foi tocado pela graça divina e se proclamou cristão, tendo sido então martirizado. A peça é original pelo estilo "vivo, animado e variado", pela mescla de elementos cômicos, trágicos, familiares e sublimes, por tocar numa questão de grande importância na época - a liberdade pessoal dos indivíduos - e, sobretudo, por inserir uma tragédia em outra: o ator, ao converter-se, estava representando o "Martírio de Adriano".

Chegamos finalmente a Racine, estrela de primeira grandeza numa constelação de teatrólogos seiscentistas, alguns dos quais sem grande brilho próprio. Jean Racine (1639-1699) começou a dedicar-se às letras muito cedo, mal saído dos bancos escolares, ${ }^{30}$ e já era um teatrólogo bem sucedido ${ }^{31}$ quando, em 1669, apresentou ao público sua primeira tragédia de assunto romano, Britannicus, provavelmente composta para fazer frente às tragédias históricas de Corneille. A peça, inspirada nos Anais (XIII, 1) de Tácito e trabalhada com profundidade, tem como argumento a morte de Britânico e leva à cena personagens históricas bem conhecidas como Nero, Otávia, o próprio Britânico, que dá título à tragédia, pondo em foco o assassínio do jovem príncipe, motivado por ciúme, segundo o teatrólogo. Sua primeira representação, no entanto, não foi recebida com o esperado entusiasmo. Só com o tempo a tragédia passou a ser admirada, revelando-se, então, suas grandes qualidades no que diz respeito à pintura dos caracteres. 
No primeiro prefácio da tragédia, Racine fala que, de todas as obras oferecidas ao público, nenhuma, como Britannicus, foi objeto de tantos aplausos e de tantas censuras. Reconhece que, quanto mais trabalhou na peça, mais seus desafetos se empenharam em nela encontrar defeitos. Houve até mesmo quem se tenha disposto a defender Nero, considerando que o autor o havia construído como uma personagem demasiadamente cruel. Em resposta a esses, Racine se defende, tomando como apoio a obra de Tácito, por ele utilizada como fonte principal. Em contraposição, houve os que censuraram a peça por achar que Nero havia sido construído como uma figura bondosa. Alguns a criticaram pelo fato de Britânico, o herói trágico, ser jovem demais para desempenhar o papel que lhe foi dado, ou por Racine ter acrescentado dois anos à idade real do príncipe, morto aos quinze anos, ou por ter criado, em Júnia, a figuração da amada de Britânico, ou por ter prolongado a peça após a morte do herói. Mais uma vez Racine se defende, tomando como argumentos a teoria de Aristóteles ou os exemplos de Sófocles. "Que seria preciso fazer para contentar juízes tão severos?", ${ }^{2}$ se pergunta Racine a si mesmo. E, após ter feito uma reflexão sobre as limitações dos críticos, termina seu prefácio com uma citação de Terêncio: Homine imperito numquam quidquam iniustius ("Não há nada mais injusto do que uma pessoa ignorante").

Racine se vale do argumento histórico em Britannicus mas lhe amplia a dramaticidade, recriando a figura de Júnia e dela fazendo a amada do príncipe e o motivo central de todo o conflito trágico. Construindo-a como uma virgem amorosa e pura, Racine trabalha com o amor dos dois jovens e, ao lado do problema político que a união poderia provocar, por ser a moça uma descendente de Augusto, acrescenta um problema de natureza passional: Nero se toma de amores por Júnia, ao vê-la, deseja-a, cobiça-a e, por não lhe conseguir as boas graças, planeja e executa o envenenamento de Britânico. As questões se cruzam, portanto. $\mathrm{O}$ próprio relacionamento problemático existente entre Agripina e Nero, ocasionado por uma luta de poder, se agrava, em Racine, pela proteção da imperatriz à união de Júnia e Britânico. Criando um conflito de natureza emocional, Racine faz dele derivar toda a tragédia.

Em 1670 o teatrólogo fez levar à cena uma nova tragédia romana, Bérénice, peça com a qual atendeu ao desafio da duquesa de Orléans que propusera a ele e a Corneille a composição de tragédias versando sobre o mesmo assunto. Bérénice conseguiu suplantar Tite et Bérénice de Corneille.

De duas pequenas referências feitas por Suetônio à princesa Berenice, Racine extraiu o assunto de sua tragédia: a referência ao fato de o Imperador ter levado a princesa Berenice a Roma, após o cerco de Jerusalém, e a que menciona o amor do 
Imperador pela princesa cativa. Com base nessas pobres referências, Racine compôs sua tragédia que, se não apresenta sangue e morte, explora um drama passional de grandes proporções.

Em 1673, Racine compôs Mithridate, a "mais corneliana" de suas tragédias, texto histórico baseado em Floro, Plutarco, Díon Cássio e Apiano, no qual, conquanto verse a peça sobre uma questão política referente ao reino do Ponto, Roma se faz presente o tempo todo. Depois de Mithridate, Racine se dedicou a tragédias mitológicas ${ }^{33}$ e bíblicas. ${ }^{34}$

Segundo Lagarde e Michard (Lagarde \& Michard, 1958, p. 286), a doutrina clássica, elaborada entre 1620 e 1660, encontra sua expressão mais perfeita nas tragédias de Racine. As regras das três unidades são respeitadas sem que pareça haver qualquer artificialismo na obediência aos princípios teóricos; os assuntos são tirados da lenda e da história e tratados com grande fidelidade, sem que o autor se escravize às fontes; a conveniência e a verossimilhança não são feridas em nenhum momento. O "ideal dramático" do autor, exposto no Prefácio de Britannicus, se concretiza na unidade de intriga, no tratamento dado à crise trágica, na progressão da ação, no desenlace. As personagens são extremamente bem construídas. A luta entre o amor e o dever é retratada em detalhes; os conflitos são intensos e as paixões se desenham em toda a sua força. A linguagem de Racine, por sua vez, seu estilo trabalhado e correto, a perfeição de seus versos, fazem com que ele seja, indiscutivelmente, um dos maiores expoentes da dramaturgia francesa de todos os tempos.

Durante o período em que Racine escreveu suas obras, outros teatrólogos franceses se dedicaram à tragédia de tema romano. É o caso de Thomas Corneille (1625-1695), por exemplo, irmão do grande Pierre Corneille, que, ao lado de enfrentar a responsabilidade e o peso do nome famoso, enfrentou também a dura competição com Racine. Fazendo sua estréia no teatro em 1647, compôs trinta e duas peças teatrais: tragicomédias, comédias, tragédias mitológicas e históricas, entre as quais Bérénice (1657), La mort de Commode (1658), Maximien (1662) e La mort d'Annibal (1669). Embora haja qualidades em seus textos e muitas de suas peças tenham feito extraordinário sucesso, ${ }^{35} \mathrm{o}$ brilho de seus dois ilustres contemporâneos não lhe permitiu que se projetasse mais.

Podemos ainda lembrar, nessa época, os nomes de Pradon e Philippe Quinault. Pradon (1632-1698) era um autor quase desconhecido em 1667, pois que suas primeiras obras ${ }^{36}$ haviam passado praticamente despercebidas, quando teve a ousadia de medir-se com Racine apresentando ao público sua tragédia Phèdre et Hippolyte, dois dias após a representação da Phèdre raciniana. Depois desse feito, que teve grande repercussão no meio teatral, Pradon compôs outras obras entre as 
quais três tragédias de assunto romano: Regulus (1688), considerada como a sua melhor obra, Germanicus (1694) e Scipion l'Africain (1697).

Philippe Quinault (1635-1688), segundo Julleville "muito superior a todos os obscuros rivais de Racine" (Julleville, 1927, p. 179), foi autor de comédias, tragicomédias, libretos de óperas e tragédias mitológicas e históricas, entre as quais Agrippa, escrita em 1663, sua única tragédia de argumento romano.

Outros teatrólogos, como Jean Campistron e Antoine La Fosse, podem ser considerados como meros seguidores de Racine. Jean Campistron (1656-1723), que se vangloriava de ser discípulo do grande mestre, nunca chegou a fazer sucesso com suas tragédias e sempre foi visto como um autor medíocre. Escreveu peças com assunto extraído da história romana tais como Virginie (1683), Arminius (1684), Adrien (1690), Aétius (1693) e Pompéia, que não chegou a ser representada durante a vida do escritor. Antoine La Fosse (1653-1708), superior a todos os teatrólogos posteriores a Racine que viveram no fim do século XVII e no início do século XVIII, compôs três tragédias mitológicas, ${ }^{37}$ de tom acentuadamente romanesco, e uma tragédia histórica, geralmente considerada como sua melhor obra: Manlius Capitolinus (1698). O assunto é tirado de Tito Lívio (VI) e o tratamento dramático sofre influência do dramaturgo inglês Thomas Otway.

O último teatrólogo francês a escrever uma tragédia "romana" no século XVII foi o abade Brueys (1640-1723), que se notabilizaria por compor comédias, sozinho ou em parceria com Palaprat. A única tragédia de Brueys é Gabinie, tragédie chrétienne, a dramatização da história do martírio de Santa Suzana, representada em 1699. O título é curioso e revela uma preocupação dos tragediógrafos que viveram entre o fim do século XVII e o início do XVIII: a criação de um vocabulário refinado, especial para a tragédia. Até os nomes próprios sofreram restrições, conforme o caso. Brueys considerou inadequado o nome Suzana para uma santa e, sobretudo, para uma heroína de tragédia. Como o pai da jovem mártir se chamava Gabinius, o dramaturgo deu à moça o nome de Gabinie (Gabínia)!

\section{Temas romanos na tragédia inglesa}

No final do século XV - não se sabe com certeza em que ano - representouse pela primeira vez na Inglaterra um drama de tema romano: Fulgens and Lucres. Desconhece-se o autor e, como não se tratava de uma tragédia, não se pode ainda falar em "herança da pretexta". Fulgens and Lucres, segundo Highet (Higuet, 1949, p. 137), é "um interlúdio, uma história de amor inspirada pela fantasia renascentista 
e baseada na história romana da época republicana". Tem conteúdo cômico semelhante ao que se observa em farsas medievais - trata da competição entre um bom plebeu e um voluptuoso patrício romano que disputam a mão de uma virtuosa mulher - e apresenta caracteres grotescos, próximos dos das comédias latinas.

A divulgação da tragédia de Muret, Julius Caesar, escrita na França, em latim, em 1544, e a tradução da pretexta Otávia, realizada por Thomas Nuce em 1561, acenderam provavelmente o gosto pelas peças históricas de assunto romano. Em data imprecisa, mas que deve situar-se entre 1565 e 1575, foi representado o drama Appius and Virginia, baseado num relato de Tito Lívio (III, 44-58) já utilizado anteriormente por Chaucer, como argumento do "Doctor's Tale". De acordo com o esse relato, Virgínia, uma jovem romana, fora apunhalada e morta por seu próprio pai ao ser reqüestada por Ápio Cláudio, um dos decênviros romanos. Segundo MacCallum (MacCallum, 1935, p. 2 s.), a peça se intitulou originalmente A new tragicall comedy of Apius and Virginia e o autor, do qual se conhecem apenas as iniciais R. B., talvez fosse Richard Bower, mestre da Capela Real de Windsor em 1559. A tragédia foi publicada em 1575 mas deve ter sido escrita alguns anos antes, por volta de 1563. É uma peça que se ressente ainda da influência das "moralidades" tanto por sua "intenção ética" proclamada no prólogo e evidenciada no correr dos episódios - um alerta contra a paixão desenfreada e libidinosa - como por apresentar, ao lado de personagens presumivelmente históricas, figuras alegóricas como a Consciência, a Fama, a Memória, a Doutrina, a Justiça.

A publicação da tradução das Vidas Paralelas de Plutarco, em 1579, feita por Thomas North, ${ }^{38}$ a partir da tradução francesa de Jacques Amyot, foi um grande impulso na divulgação de fatos da história antiga que se prestavam a encenações teatrais.

Entre 1580 e 1590, o drama se renova na Inglaterra e começa a ser considerado como uma das glórias da literatura inglesa. Conforme afirma Émile Legouis (Legouis, 1953, p. 119 s.), o número e a diversidade das peças então produzidas torna a classificação difícil. Não se pode, é certo, fazer um resumo retrospectivo do que ocorreu nessa época por falta de alguns dados. Não só a cronologia das peças remanescentes é algo duvidosa como muito do que foi produzido se perdeu. Grandes dramaturgos começam, entretanto, a aparecer nesse período, dedicando-se a diversas modalidades dramáticas: John Lily, George Peele, Thomas Kyd, Cristopher Marlowe, Robert Greene; são os antecessores imediatos daquele que viria a ser o maior teatrólogo da época elizabetana: William Shakespeare (1564-1616).

Vindo de Stratford-on-Avon, para Londres, em 1590, Shakespeare se firmou não só como ator mas também como autor de incrível versatilidade, compon- 
do comédias, tragédias, tragicomédias e dramas históricos, mesclando-se entre os últimos os dramas cujo assunto é extraído da história da Inglaterra e os que exploram fatos da história romana ou grega. Como heranças da pretexta latina - dramas baseados na história de Roma - temos Julius Caesar, Coriolanus e Antony and Cleopatra. A elas poderíamos justapor a discutível tragédia Titus Andronicus, ${ }^{39}$ que explora um episódio bastante difundido durante a Idade Média, extraído presumivelmente da história romana recente. Como, entretanto, pairam algumas dúvidas sobre a autoria dessa tragédia e sobre as fontes históricas que teriam sido consultadas para a elaboração do texto ${ }^{40}$ - não se tem nem mesmo certeza de que Tito Andronico, apresentado como um general romano, tenha realmente existido - abstemo-nos de fazer maiores comentários sobre a obra, detendo-nos naquelas que são consideradas como tragédias que focalizam um fato histórico efetivamente ocorrido.

Julius Caesar talvez seja a mais conhecida das três tragédias "romanas" de Shakespeare. Publicada em 1623, foi possivelmente composta em 1599, tendo sido representada pela primeira vez nesse ano. ${ }^{41}$ Por seu tom e conteúdo costuma ser associada a Hamlet, de 1602, como uma "tragédia de reflexão". O tema da tragédia é a morte de Júlio César, fato histórico bem documentado e, segundo Ribner e Kittredge (SHAKESPEARE, 1971, p. 1006) o evento mais conhecido da história romana, durante todo o Renascimento. Valendo-se, como fonte, das Vidas Paralelas, de Plutarco, e de As guerras civis, de Apiano, e provavelmente de outras fontes, tais como as cartas escritas por Cícero a Ático logo após o assassínio de César, as Filípicas, de Cícero, a Farsália, de Lucano, e os textos históricos de Suetônio e Díon Cássio, Shakespeare mostra em seu drama alguns fatos que precederam a morte de César, o assassínio perpetrado por um grupo de romanos e as conseqüências do crime político: o funeral de César, com os discursos de Bruto e Marco Antônio, a chegada de Otávio a Roma, a formação do segundo triunvirato e a batalha de Filipos.

O exame do texto permite-nos fazer uma série de observações.

Quanto à questão das unidades, pode-se dizer que há certa unidade de ação. Não há, porém, nem unidade de espaço nem de tempo. Muitos são os cenários em que decorrem as cenas (ruas e praças de Roma, jardim da casa de Bruto, quarto da casa de César, Capitólio, Forum, quarto da casa de Marco Antônio, acampamentos militares, tenda de Bruto, planície macedônica). $O$ tempo equivale a pouco mais de dois anos e meio (de fevereiro de 44 a setembro de 42 a.C.).

Quanto à progressão da ação, o ritmo é convencional. O texto é dividido em cinco atos e cada ato corresponde a um dos momentos que marcam a progressão: situação inicial; intensificação da ação; clímax; relaxamento da ação; desfecho. 
Há certa preocupação com a verossimilhança, sobretudo no que diz respeito à ambientação. Shakespeare procurou criar um "clima" romano, fazendo algumas alusões de caráter mitológico e referências a usos e costumes da época retratada: às lupercais, ao adivinho que dirigira a palavra a Júlio César durante a procissão, recomendando-lhe que se acautelasse com os "idos de março", às superstições típicas do povo romano, tais como o fato de um homem tocar uma mulher estéril na festa dos Lupercos para torná-la fértil, à crença em prodígios noturnos - tempestade, raios, gritos de aves noturnas, presença de uma leoa pelas ruas. Não conseguiu, porém, fugir dos anacronismos que aparecem a todo momento no decorrer da peça: na primeira cena do primeiro ato, por exemplo, Marulo fala do o avental de couro que um carpinteiro estava usando (I, 1, 7); na segunda, Cássio se considera como um "espelho" de Bruto, empregando a palavra glass, designativa de espelho de vidro ou cristal (I, 2, 68); Casca se refere aos cidadãos que atiraram seus gorros para o ar, quando César recusou a coroa oferecida por Marco Antonio (I, 2, 247), e à jaqueta usada por César (I, 2, 267); na primeira cena do segundo ato, Lúcio se refere aos conspiradores que procuram Bruto, falando de seus chapéus "enterrados até as orelhas" (II, 1, 73); mais adiante há uma rubrica, indicando que um relógio bate as horas, e referências feitas por Cássio e Bruto tanto ao relógio propriamente dito quanto ao número de batidas (II, 1, 192); na segunda cena desse mesmo ato, há outra referência às batidas de um relógio (II, 2, 114); na terceira cena do quarto ato, Bruto se refere a um livro que encontrara no bolso de sua túnica (IV. 3, 252-253) e a uma página desse livro, que fora marcada por ele ao interromper uma leitura (IV, 3, 273-274).

Esses anacronismos não chegam a comprometer a verossimilhança. Mais problemática, no entanto, é a questão da aparição do espírito de Júlio César a Bruto na cena III do ato IV. Embora o episódio possa ser interpretado como uma espécie de visão onírica de um homem totalmente desesperançado e ligeiramente embriagado, submetido a toda espécie de pressões, há um espírito de morto que entra na tenda de Bruto e dialoga com ele, fazendo uma alusão à futura batalha de Filipos e à desgraça do conspirador.Trata-se, sem dúvida, de um belo efeito teatral construído por Shakespeare, semelhante ao que se observa em Hamlet e influenciado possivelmente por tragédias de Sêneca.

No que diz respeito ao decoro preconizado por Horácio e, sobretudo por Boileau, às regras de conveniência que impediam cenas de extrema violência ou atentatórias ao pudor, a tragédia inglesa não lhes deu importância. Em Julius Caesar, como em Hamlet e em outras tragédias de Shakespeare, crimes sangrentos são perpetrados diante do público com a maior naturalidade. 
Quanto às personagens, Bruto é o "herói" de Julius Caesar, a personagem que mais se salienta na ação. Júlio César só aparece em três cenas e não chega a impressionar como personagem. Só se justifica o título da peça porque César é realmente o motivo do enredo: tudo gira em torno de sua morte e das conseqüências que dela advieram.

Caracterizado por Shakespeare como uma pessoa essencialmente nobre, Bruto é um filósofo e um idealista, considerado por Verity (Shakespeare, 1952, p. xx) como "um homem de especial sensibilidade e ternura sob a capa de contenção estóica que via de regra o marca". A nobreza de seu caráter não é contestada por ninguém. Tanto seus aliados, a exemplo de Cássio e Cina, como seus desafetos, a exemplo de Marco Antônio, a reconhecem. Bruto exerce grande liderança sobre os companheiros e essa liderança se articula com a nobreza de caráter, o patriotismo e a ideologia política. Para Bruto, Roma, como república, está acima de tudo. A preservação dos ideais republicanos o fazem agir, lutar, tomar decisões que jamais gostaria de ter tomado. É em nome da república que Bruto se alia aos conspiradores que atentam contra Júlio César; para ele, matar um tirano é prestar um serviço a Roma.

Embora não tenha sido caracterizado de forma tão minuciosa como Bruto, já que seu papel é de um deuteragonista, Marco Antônio é uma personagem bem construída e instigante. Contrariamente ao que ocorre com Bruto, não é o idealismo o que o leva à ação, mas o oportunismo, o desejo de aproveitar-se das circunstâncias em benefício próprio. Contrariamente, também, ao que ocorre com Bruto, Marco Antônio se mostra capaz de dominar o povo inculto, conhece sua psicologia, sabe fazê-lo trilhar o caminho indicado. A oração fúnebre que pronuncia faz profundo contraste com o discurso de Bruto e leva o povo a apoiá-lo.

Quanto a Júlio César, embora seja a personagem-título da tragédia, o elemento desencadeador de todo o drama, é construído, no dizer de A. W. Verity (Shakespeare, 1952, p. xxviii), com certa majestade, mas sem o vigor que marcara o ditador em sua juventude. Não é mais o conquistador da Europa ocidental, mas, sim, um homem decaído, enfraquecido tanto no corpo como na mente. Embora orgulhoso, embora se proclame como mais perigoso que o próprio perigo (II. ii. 4445) e se considere a si próprio como uma espécie de divindade infalível, dá mostras iniludíveis de fraqueza.

As duas mulheres presentes no texto, Pórcia, esposa de Bruto, e Calpúrnia, de César, merecem uma observação especial. Shakespeare trabalha esses caracteres, sem grande auxílio de fontes, uma vez que as Vidas de Plutarco não dão maior relevo a figuras femininas. Pórcia surge no texto como uma espécie de alter ego de 
Bruto. Assim como ele não pode se esquecer de quem é, Pórcia é também consciente do valor que tem: esposa de Bruto, filha de Catão, bem nascida e bem casada, por conseguinte. De natureza sensível e terna, partilha das preocupações do esposo e procura auxiliá-la no que lhe é possível, na medida de suas forças, sem suspeitar do alcance da participação de Bruto na conspiração contra César.

Calpúrnia tem um papel pequeno. No principal diálogo que mantém com César, na segunda cena do segundo ato, revela suas características: é supersticiosa - não admite a idéia de que César possa sair de casa nos "idos de março" e acredita em presságios -, amedronta-se com cerimônias públicas, receia pelo bem-estar do esposo. Não tem força persuasiva suficiente, entretanto, para impedi-lo de dirigirse ao Senado, no dia fatídico, e encontrar, em decorrência, a morte.

As qualidades dramáticas de Julius Caesar garantiram-lhe o sucesso. A peça foi bem recebida desde a primeira representação e a crítica sempre se mostrou favorável a ela. Embora outros teatrólogos, a exemplo de Munday, Drayton, Webster, Middleton, tenham tentado imitá-la, retomando o tema da morte de César, a tragédia de Shakespeare se manteve, em sua novidade, como uma peça bem sucedida, talvez o melhor e o mais profundo drama histórico escrito pelo autor.

Antony and Cleopatra, se não pode ser considerada apenas como uma espécie de continuação de Julius Caesar, volta a trazer ao público duas importantes personagens históricas, presentes no primeiro drama: Otávio e Marco Antonio. Após a batalha de Filipos e a vitória sobre Bruto e Cássio, Otávio e Marco Antonio dividiram o poder, partilhando-o com Lépido e assim constituíram o segundo triunvirato. A tragédia focaliza o momento em que, já desfeito o triunvirato, Otávio e Marco Antônio se desentendem, dando ocasião à batalha de Ácio. Nessa batalha, ocorrida em 31 a.C., Otávio venceu as forças de Marco Antônio, que se aliara a Cléopatra, e a derrota deu motivo à morte do casal.

Antony and Cleopatra é, sem dúvida, uma das mais belas tragédias de Shakespeare. Marlene Soares dos Santos, que faz a "Introdução" à tradução do texto, realizada por José Roberto O'Shea (Shakespeare, 1997, pp. 7-20), compara Antony and Cleopatra a Romeu e Julieta, uma vez que ambas as peças exploram casos de amor que terminam em suicídio dos protagonistas. Mostra, então, as diferenças que existem entre as duas tragédias: Romeu e Julieta são extremamente jovens e inexperientes, se apaixonam pela primeira vez, se casam e não se envolvem em problemas políticos; Antônio e Cleópatra são pessoas maduras que já passaram por outras experiências amorosas e desempenham papéis importantes na vida política de seus países. As questões referentes ao poder conferem grande den- 
sidade dramática à tragédia. Os pontos comuns que encontramos nos dois textos Romeu e Antônio se matam por pensarem que Julieta e Cleópatra estavam mortas; Julieta e Cleópatra se matam por serem incapazes de continuar vivendo sem a presença de seus amantes - apresentam diferenças uma vez que na morte de Romeu e Julieta a única motivação é o amor perdido e na de Antônio e Cleópatra fatores de natureza política se aliam à morte do ser amado.

Prosseguindo em sua análise, M. S. Santos faz outras reflexões importantes. Para ela uma questão interessante diz respeito ao enfoque da posição de Antônio/ Cleópatra diante de César, vencidos na guerra e vencedores por burlarem os planos do vencedor; outra questão diz respeito à dualidade da peça, na qual o conflito externo (Roma versus Egito) corresponde ao conflito interno de Antônio, dividido entre os dois mundos. Há, na verdade, outros dualismos na peça: as antinomias dever/prazer, lealdade/traição, confiança/desconfiança se estampam a todo momento, movimentando a peça.

Mais do que drama histórico, Antony and Cleopatra é a tragédia de uma paixão fatal. Não se constitui, como dissemos, em mera continuação de Julius Caesar e, apesar de ter alguma afinidade com tal peça tanto pela influência de Plutarco quanto pela própria linguagem, está mais próxima de Romeo and Juliet pela estrutura dramática e pelo desfecho. Quanto ao assunto que explora, Antony and Cleopatra é, sem dúvida, a mais elaborada das tragédias romanas de Shakespeare.

Coriolanus, ao contrário, tem enredo relativamente simples. A peça se inspira na história de Caio Márcio Coriolano, general romano que teria vivido no século $\mathrm{V}$ a.C. e que fora processado, exilado e morto após ter lutado contra os volscos. Quanto às fontes utilizadas por Shakespeare, a principal, como ocorreu com Julius Caesar e Antony and Cleopatra, foi o capítulo dedicado a Coriolano, contido nas Vidas Paralelas de Plutarco. ${ }^{42}$ Dionísio de Halicarnasso (Antigüidades Romanas) e Lúcio Floro (Histórias Romanas) também se ocuparam do assunto mas não se sabe se Shakespeare os teria utilizado como fontes. Coriolano é um herói semi-lendário, pertencente ao primeiro período da história romana. Conforme Plutarco, fora ele, em sua condição de patrício, investido das funções de general na guerra contra os volscos. Vitorioso na guerra, foi acusado pelos romanos de aspirar a tirania, sendo em decorrência processado e exilado. Desgostoso, aliou-se aos inimigos, cujo exército passou a conduzir, dirigindo-se, então, a Roma e submetendo as cidades que se encontravam em seu caminho. Entretanto, cedendo a súplicas de sua mãe e de sua esposa, abandonou o exército e refugiou-se em Âncio, onde foi morto pelos antigos inimigos. 
Shakespeare teatraliza o relato de Plutarco, condensando a história, diminuindo ou aumentando a importância de certos fatos e eliminando alguns pormenores. Na composição de personagens, trabalha com sua criatividade, exagerando a rude arrogância do general, criando a figura do jovem Márcio, filho de Coriolano, e fazendo de Volúmnia, a mãe do herói, uma pessoa que, segundo ele, exercia grande influência sobre o filho e era capaz de persuadi-lo com facilidade.

Segundo Ribner e Kittredge (SHAKESPEARE, 1971, p. 1375), nada se sabe ao certo sobre a data da composição de Coriolanus e de suas primeiras representações. Foi publicada pela primeira vez em 1623. Acredita-se que tenha sido uma das últimas peças dramáticas de Shakespeare, escrita entre 1608 e 1609 É provavelmente posterior à tragédia Coriolan, composta pelo teatrólogo francês Alexandre Hardy, por volta de 1600, mas é possível que o dramaturgo inglês não a conhecesse uma vez que a tragédia francesa só foi publicada em 1625.

Não incluímos Cymbeline, peça publicada em 1623, entre as tragédias "romanas" de Shakespeare, uma vez que, embora seu enredo gire em torno de Cunobelinus, ${ }^{43}$ governador da Britânia, não é a rigor uma tragédia por não apresentar os conflitos que caracterizam tal modalidade dramática.

Na mesma época em que Shakespeare começou a produzir textos dramáticos outros dramaturgos se dedicaram à composição de tragédias de argumento romano, na Inglaterra. Em 1592 foi publicada a tradução da tragédia Marc Antoine, de Garnier, realizada pela Condessa de Pembroke, irmã de Sir Philip Sidney. Dois anos mais tarde, em 1594, Samuel Daniel publica a tragédia Cleopatra, dedicandoa à Condessa de Pembroke. Na dedicatória, com muita humildade, agradece à condessa o estímulo que ela lhe deu com a tradução do trabalho do dramaturgo francês. Cleopatra revela grande influência das tragédias de Sêneca e se aproxima, pela construção tanto da Cléopâtre Captive de Jodelle como do Marc Antoine de Garnier. MacCallum a considera ultrapassada até mesmo para a época em que foi escrita. Para ele, não se trata propriamente de uma peça teatral, mas, sim, de uma série de arengas intercaladas com pedaços de diálogos e cantos corais. Entre os longos monólogos pode-se lembrar o solilóquio de Cleópatra, que ocupa todo o primeiro ato, a descrição da prisão da rainha, feita por Proculeio no segundo ato, o discurso de Seleuco, no quarto ato e o relato de Tício no quinto. Alguns diálogos de caráter filosófico, como o que se trava entre Filostrato e Ário, não são suficientes para quebrar a monotonia do texto (MacCallum, 1935, p. 51).

Nesse mesmo ano de 1594, além da publicação de Cornelia, tradução da Cornélie de Garnier, levada a termo por Kyd, foi publicada a tragédia The wounds of 
civil war, escrita por Thomas Lodge por volta de 1589. A tragédia de Lodge se baseia no obra de Apiano e tem como argumento a guerra civil que se travou entre Mário e Sila, no século I a.C. Entre o fim do século XVI e o início do século XVII, outros autores de menor porte se dedicaram às tragédias de argumento romano: Mary Herbert compôs Antony, tragédia que se ressente de profunda influência de Sêneca; George Chapman (1550-1634) escreveu Caesar and Pompey e John Marston (1575?-1634), Antonio and Mellida, Antonio's Revenge e Sophonisba.

Nenhuma dessa tragédias, no entanto, pode comparar-se às de Ben Jonson e Philip Massinger, que se destacam no período shakespeareano como dramaturgos importantes.

Ben Jonson (1573?-1637), mais conhecido pelo tom satírico ${ }^{44}$ e cômico ${ }^{45}$ que conferiu a algumas obras anteriores, escreveu duas tragédias históricas de tema romano: Sejanus (1603) e Catiline (1611). Segundo Legouis (Legouis, 1953, p. 138), o dramaturgo compôs essas tragédias com a intenção de competir com Shakespeare, cujo Julius Caesar lhe havia mostrado a possibilidade de interessar o público com uma tragédia de assunto histórico, explorando fatos ocorridos na Antigüidade. Além do mais, Ben Jonson se considerava grande conhecedor da História Antiga, capaz de mostrar ao espectador uma Roma autêntica, diferente da "Roma londrina" sugerida por Shakespeare. As peças são construídas com vigor, a erudição do tragediógrafo é incontestável e os temas tratados são interessantes - tanto a história de Sejano, o "braço direito" de Tibério que acabou por cair em desgraça perante o Imperador, como a de Catilina, cuja conjuração foi descoberta por Cícero. O excesso de sátira, porém, causa certo desconforto ao espectador.

Philip Massinger (1583-1639), autor de numerosas comédias muito bem sucedidas, em que o tom satírico ultrapassa o meramente cômico, ${ }^{46}$ mostrou-se capaz de escrever também obras sérias a exemplo de The Roman actor (1626). Conforme a opinião de Legouis (Legouis, 1953, p. 149), The Roman actor ombreia com Sejanus de Ben Jonson, podendo até mesmo ser-lhe considerada superior pelo interesse que desperta. Explora a história do ator Páris, por quem se apaixonara a imperatriz Domícia. Por rejeitar o amor da nobre dama o ator foi condenado à morte. $\mathrm{O}$ estilo de Massinger é vigoroso e sólido e seus versos são perfeitos, o que não isenta os dramas que escreve de certa monotonia.

No último quartel do século XVII, são feitas novas incursões pela tragédia romana. Em 1678, John Dryden, figura que se tornara conhecida nos meios literários desde 1666, compôs All for Love, or The World Well Lost, fazendo uma espécie de "revisão" independente do Antony and Cleopatra de Shakespeare. Em 1681, 
Nathaniel Lee publicou Theodosius or the Force of Love. São tragédias barrocas em que, como os próprios títulos indicam, o conflito se estabelece a partir do amor.

\section{Temas romanos na tragédia espanhola}

Não há muitas informações sobre as obras teatrais compostas na Espanha durante a Idade Média. Os primeiros textos destinados à representação na corte, preservados para a posteridade, são da autoria de Gomes Manrique (1412-1490) e foram compostos em meados do século XV. Conservam a temática religiosa dos "mistérios" medievais (Representación del nacimiento de Nuestro Señor, Lamentaciones hechas para Semana Santa) mas já deixam entrever o espírito renascentista. O teatro profano representado por églogas e farsas encontra seus principais cultivadores nas figuras de Lucas Fernández (1474-1542) e Juan del Enzima (1469-1530), teatrólogos que compuseram suas peças entre o fim do século XV e o início do século XVI. ${ }^{47}$

Foi nessa época que, segundo Angel Valbuena Prat (Prat, 1950, p. 777 s.), começaram a surgir as primeiras tentativas de aclimatar-se na Espanha a tragédia greco-latina. $\mathrm{O}$ espírito espanhol, entretanto, foi sempre um pouco avesso à simplicidade do drama clássico. Os dramaturgos da Espanha nunca se preocuparam com a análise minuciosa da personalidade das personagens, nem com as ações lentas e unificadas; preferiram explorar o ímpeto barroco de uma intriga complexa, em torno da qual tipos diversos se cruzam rapidamente. Daí, segundo o mesmo autor, o fato de as tentativas de imitação dos clássicos terem sido quase sempre infrutíferas.

Hernán Perez de Oliva (1494-1531) é o primeiro a tentar a composição de comédias e tragédias nos moldes clássicos. ${ }^{48}$ Suas obras, porém, não chegaram a desfrutar de maior importância. No segundo e terceiro quartéis do século XVI, surgem as figuras de Lope de Rueda (1505-1565), ,9 Jerónimo Bermudez (15301599), ${ }^{50}$ e Cristóbal Viruez. ${ }^{51} \mathrm{O}$ teatro espanhol, entretanto, só iria produzir seus grandes frutos nos últimos anos do século XVI e, sobretudo, no século XVII, com Cervantes, Lope de Vega, Tirso de Molina e Calderón de la Barca.

Em 1580, depois de ter passado cinco anos em cativeiro, em Argel, Miguel de Cervantes (1547-1616) retorna à Espanha, fixa residência em Madri e se dedica ao teatro. Entre 1582 e 1587 escreve três peças teatrais: Los tratos de Argel, La destruición de Numancia e La batalla naval. Interessa-nos a segunda, por tratar-se de uma peça com assunto extraído da história de Roma. Para escrevê-la, Cervantes se utilizou de informações oferecidas pelo cronista Ambrosio de Morales, pela 
Corónica de España abreviada, de Diego de Valera, e pelas Epístolas familiares de Fray Antonio de Guevara. Não se sabe se ele teria tido acesso a fontes antigas, tais como a epítome do livro LIX de Tito Lívio, na qual se diz que o triunfo de Cipião foi celebrado em Roma catorze anos após a vitória do general sobre Cartago, e as obras de Apiano, Eutrópio e Paulo Orósio.

La destruición de Numancia, como o próprio título indica, é uma tragédia que se ocupa dos problemas ocorridos entre Roma e Numância, em fins do século II a.C., quando a cidade hispânica foi sitiada por Cipião Emiliano. O general romano empregou o método grego de assédio para obrigar os numantinos à rendição, cercando a cidade e impedindo a saída dos moradores. Estes, porém, ao contrário do que os romanos esperavam, não se entregaram: enfrentaram a fome e as doenças e morreram, em sua grande maioria, antes que os romanos conseguissem entrar na cidade.

A tragédia de Cervantes não é uma simples reconstrução arqueológica de um fato histórico passado. O teatrólogo se vale de um episódio verídico da história hispânico-romana, mas lhe dá características tipicamente dramáticas, enfatizando pormenores, pondo em realce idéias filosófico-ideológicas e criando personagens ficcionais, de grande força dramática, que se mesclam a vultos históricos. Compõe, dessa forma, valendo-se de metros freqüentes na poesia peninsular (estrofes rimadas, em versos decassílabos e em redondilhas), um poema trágico de exaltação ao valor e ao denodo dos antepassados dos espanhóis que opera como verdadeiro libelo contra a opressão dos poderosos.

Após a publicação e a representação de La destruición de Numancia, não foram numerosas as peças de argumento romano compostas na Espanha. No século XVII, época de ouro do teatro espanhol, os grandes teatrólogos Lope de Vega (1562-1635), Tirso de Molina (1580-1648) e Calderón de la Barca (1600-1681) se dedicaram sobretudo a comédias e a tragédias de assunto patriótico ou religioso. Lope de Vega ensaiou seus passos pelo campo da pretexta ao escrever Honrado Hermano, drama que explora o assunto da luta entre Horácios e Curiácios que já fora tratado por Aretino, na Itália e que será explorado magistralmente por Corneille, na França, alguns anos depois. Calderón de la Barca compôs dois dramas de assunto romano, Las armas de la hermosura e El segundo Escipión, ao lado de dois outros que apresentam alguma vinculação com a história de Roma: El mágico prodigioso e Las cadenas del Demonio. Em Las armas de la hermosura, peça composta provavelmente em 1652, Calderón de la Barca retoma a história de Coriolano, já tratada por Shakespeare, mas, ao contrário do dramaturgo inglês, se afasta bastante de Plutarco, 
dando asas à fantasia; em El segundo Escipión, representada pela primeira vez em 1677, no Palácio Real de Madri, desenvolve o argumento do cerco de Cartago, extraído dos livros XXVII, XLII e XLVII de Tito Lívio. A peça se caracteriza pela mescla de elementos dramáticos e cômicos - ficando a comicidade por conta dos palhaços Turpin e Brunel - e pela presença de cenas tocantes, produto da imaginação do autor. A súplica das mulheres cartaginesas é uma criação de Calderón como também o é a insinuação da paixão do general romano por uma bela cativa de Cartago.

Em El mágico prodigioso e Las cadenas del Demonio a presença de Roma é acidental. $O$ primeiro drama se passa em Antioquia e sua figura central é São Cipriano; o segundo, na Armênia, sendo São Bartolomeu o protagonista. São dramas cristãos, portanto, vividos por figuras vinculadas por alguma razão ao poderio de Roma: Cipriano era cartaginês, foi bispo de Cartago e, embora tenha escapado à perseguição determinada por Décio, foi investigado, exilado e condenado à morte na época de Valeriano; Bartolomeu foi um dos discípulos de Cristo e teria sido provavelmente martirizado em Roma no século I.

São essas as formas pelas quais Roma incorre na dramaturgia espanhola dos séculos XVI e XVII.

\section{A tragédia romana em Portugal na época renascentista}

Embora tenha havido representações teatrais em Portugal durante a Idade Média, são poucas as informações seguras sobre o assunto. Como ocorreu em outros locais do mundo ocidental, as peças medievais produzidas em Portugal versavam sobre assunto bíblico ou sobre a vida dos santos. A Igreja, que comandava a cultura, comandou também o teatro. A arte cênica era vista como uma forma de catequese por transmitir ensinamentos e avivar a fé.

Uma das mais antigas referências ao teatro português se encontra na Vida e feitos de D. João II, de Garcia de Rezende. Diz o autor que por ocasião do casamento do príncipe herdeiro, Dom Afonso, foram representados numerosos "momos reais", "tantos, tão ricos e galantes, com tanta novidade e diferenças de entremezes que nunca outros tais foram vistos" (FERREIRA, s/d, p. 200). Não há referências, porém, a textos ou a teatrólogos. Os primeiros dramaturgos portugueses começam a ser conhecidos no século XVI, quando se publicam e se representam farsas e autos de Gil Vicente, ainda muito próximos do teatro medieval, comédias de Camões, tragédias de Antonio Ferreira e de Sá de Miranda. É de Sá de Miranda o único texto dramático de tema romano composto em Portugal durante o Renasci- 
mento. Trata-se da tragédia Cleópatra, escrita provavelmente em 1557, depois que o autor voltou da Itália. Dessa tragédia sobraram apenas 12 redondilhas maiores que transcrevemos a seguir, como mera curiosidade:

Amor e Fortuna são

dous deuses que os antigos

ambos os pintaram cegos.

Ambos não seguem razão

ambos os mores amigos

põem em mais desassossego.

Ambos não têm piedade

ambos se passam sem tino

do querer ao não querer.

Ambos não tratam verdade:

Amor é cego e menino.

Fortuna é cega e mulher (FERREIRA, s/d, p. 282).

Talvez o trecho pertença a um cântico coral, talvez ao monólogo de alguma personagem. É mais uma lembrança, entretanto, da pretexta latina e é o produto de um momento muito especial para a literatura portuguesa.

\section{À guisa de uma conclusão (provisória)}

A investigação cujos resultados aqui apresentamos está apenas em sua fase inicial mas já pode dar uma idéia do panorama constituído pela dramaturgia de temas romanos, no mundo. São incontáveis as peças que os exploraram na época renascentista e barroca. É imenso o campo de estudo que se estende diante de nós. Seria necessário muito tempo, muita disponibilidade, para que se desse conta de uma análise exaustiva, em profundidade e extensão. E estamos apenas no início de um trabalho. Em um momento próximo, dando seqüência a nosso estudo, pretendemos abordar as projeções da pretexta latina nos séculos XVIII, XIX e XX, lançando os olhos também para a influência exercida pela história de Roma sobre o romance e a filmografia universal.

É impressionante verificar como os pobres fragmentos das pretextas latinas, somados aos das epopéias romanas do período helenístico e ao instigante texto de Otávia, puderam operar como alimento de um imenso edifício, construído durante séculos, graças ao trabalho, à pesquisa e à paixão de escritores que se disseminaram pelo mundo e deixaram como herança para os pósteros o monu- 
mento das obras que compuseram - os textos que põem em relevo, em meio a fantasias e criações, a fascinante história da Cidade Eterna.

\section{NOTAS}

* Professora Titular do PPG Letras Clássicas da FFLCH/USP.

1 A tragédia pretexta (fabula praetexta ou praetextata) era assim denominada porque, uma vez que seu assunto era extraído da história romana, os atores se vestiam com togas pretextas, a indumentária própria dos magistrados, e não com vestes gregas.

2 Horácio, na Arte Poética (Epist. II, 3, 285-288), elogia os autores de tragédias pretextas: "Os nossos poetas nada deixaram sem experimentar e não muito pequeno louvor mereceram os que ousaram abandonar as pegadas dos gregos e celebrar os feitos nacionais ou os que fizeram representar as peças pretextas ou as togadas" (Nil intemptatum nostri liquere poetae,/ nec minimum meruere decus uestigia Graeca/ ausi deserere et celebrare domestica facta,/ uel qui praetextas uel qui docuere togatas). A tradução dos versos de Horácio é de Dante Tringali (Tringali, 1993, p. 35).

3 Para maiores informações sobre o assunto consultar a obra de Nevio Zorzetti intitulada La pretesta e il teatro latino arcaico (Zorzetti, 1980, p. 29-52).

4 Embora não se conheça o assunto dessas pretextas, é possível que em Rômulo - uma espécie de canção de gesta, segundo Bayet (Bayet, 1962, p. 55) - se explorasse a morte do fundador da Cidade e, em As sabinas, o rapto das mulheres, ocorrido no início do reinado de Rômulo, segundo as lendas históricas.

5 Em Clastídio, o argumento seria provavelmente a vitória de Cláudio Marcelo sobre os gauleses, em 222 a.C. Em Ambracia, a tomada da cidade homônima por Fúlvio Nobilior, em 189 a.C., durante a guerra da Etólia.

6 Em Paulo, homenageou-se o triunfo de Emílio Paulo em Pidna, em 168 a.C.; em Décio e Bruto foram dramatizadas as vitórias de generais romanos sobre samnitas e etruscos, respectivamente.

7 Segundo Léon Herrmann (Sénèque, 1971, p.xiv), o texto de Otávia se encontrava no chamado Codex Etruscus, manuscrito do século XI ou XII por ele considerado como a fonte mais segura das tragédias senequianas.

8 P. L. Cano e J. Lorente (Cano \& Lorente, 1985), com Espectacle, amor i martiris al cinema de Romans, realizaram um importante trabalho sobre a presença de temas romanos na cinematografia

9 Muitos outros dramaturgos dos séculos XVII e XVIII se ocuparam, depois de Trissino, da história trágica de Sofonisba: John Marston, Corneille, Nathaniel Lee, James Thomson, Antoine de Montchrétien, Jean de Mairet, Mellin de Saint Gelais, Claude Mermet, Nicolas de Montreux, Corneille, Voltaire.

10 No ato V, por exemplo, quando Sofonisba, sua confidente Ermínia e as mulheres do coro dialogam, todas essas características podem ser observadas.

11 A lenda dos Horácios e Curiácios será explorada mais tarde na França por Corneille, em Horace. 
12 Segundo Petit de Julleville (Julleville, 1927, p. 71), as lutas religiosas que se travam em meados do século XVI foram fator decisivo para a substituição dos "mistérios", condenados pelos protestantes, por outros gêneros dramáticos.

13 Entre os escritores que se dedicaram a traduções de peças teatrais gregas e latinas cumpre lembrar Lazard de Baïf, Charles Etienne, Pierre de Ronsard e Jean Antoine de Baïf.

14 M. W. Maccallum (Maccallum, 1935, p. 20-27), ao estudar as influências sofridas por Shakespeare, faz um interessante estudo sobre Muret.

15 Além de Cléôpatre e Eugène, Jodelle escreveu Didon se sacrifiant, tragédia inspirada na Eneida de Virgílio e bastante influenciada pelos textos de Sêneca.

16 Dividida em cinco atos, a peça se inicia com o aparecimento do espírito de Marco Antonio, que relata seu suicídio e anuncia o de Cleópatra; a rainha conversa com mulheres e se lamenta por ter sido a causa da ruína do romano; o coro das mulheres deplora a inconstância do destino. No segundo ato, Otaviano e Agripa fazem comentários sobre a morte de Marco Antonio e o coro fala sobre o orgulho humano e os castigos infernais. No terceiro ato, Cleópatra tenta comprar sua liberdade e o coro prevê que ela não suportará a escravidão. No quarto, Cleópatra é repelida por Otaviano e anuncia seu suicídio; o coro a lamenta; no quinto, a morte de Cleópatra é anunciada e, mais uma vez, o coro a deplora.

17 A atitude de Jodelle, compondo uma tragédia francesa de assunto histórico, baseado na história romana, pode ser considerada como resposta às sugestões de Du Bellay. Daí a aprovação de Ronsard e dos poetas da Pléiade.

18 Grévin escreveu La mort de César aos vinte anos.

19 O gosto pelo "debate oratório" se une à utilização de outros procedimentos senequianos muito comuns tais como a troca rápida de réplicas, "que se cruzam e se entrechocam como espadas" (Lagarde \& Michard, 1959, p. 168) e a inserção de máximas filosóficas (sententiae) no corpo do discurso.

20 Entre 1596 e 1604, Montchrestien publicou L'Écossaise, Les Lacènes, David, Aman e Hector.

21 Veja-se, por exemplo, Didon se sacrifiant, Méléagre, Alceste, Mort d'Achille.

22 Mairet fez sua estréia no teatro em 1620, com a tragicomédia Chriséide et Arimand; escreveu em seguida as pastorais Silvie (1621) e Sylvanire ou la morte-vive (1625), a comédia Les galanteries du Duc d'Ossone (1627), a tragicomédia Virginie (1628); após as tragédias romanas compôs a tragédia Le grand et dernier Soliman (1680), as tragicomédias L'Athenaïs (1635), Roland Furieux (1636), Lillustre corsaire (1637) e Sidonie (1637). François Ogier havia defendido a tragédia que não respeita a lei das "três unidades". Mairet, em 1631, combateu tal idéia no prefácio de sua tragédia Sylvanire, fundamentando-se na prática italiana e citando sua Sophonisbe como um exemplo da aplicação da lei.

23 A obra de estréia de Corneille foi a comédia: Mélite (1629); escreveu em seguida a tragicomédia Clitandre (1632), as comédias La veuve (1633), La galérie du palais, La suivante e La Place Royale (1634), a tragédia Médée (1635), a comédia Lillusion comique (1636) e a tragicomédia Le Cid (1636), com a qual obteve seu primeiro grande sucesso. 
24 Díon Cássio fornece detalhes precisos sobre a conspiração; Apiano dá informações sobre Torânio, o tutor de Otávio, cuja morte, de acordo com Corneille, teria sido o principal motivo para a conspiração de Cina.

25 Le menteur (1644), La suite du menteur (1644), Don Sanche d'Aragon (1651) e Pertharite (1652).

26 Rodogune (1645) e Agésilas (1666).

27 Andromède (1650) e Oedipe (1659).

28 Le toison d'or (1661).

29 A primeira tragédia de Tristan l'Hermite, coroada de grande sucesso, foi Mariamne (1636), uma peça sobre Herodes. Escreveu ainda as tragédias Panthée (1637) e La mort du grand Osman (1656).

30 A primeira peça de Racine foi Amasie. Era uma obra de juventude e foi recusada pelo teatro do Marais.

31 As primeiras tragédias de Racine - La Thébaïde (1664) e Alexandre le Grand (1665) foram bem recebidas. Foi com Andromaque (1667), no entanto, que a plena maturidade do teatrólogo se revelou.

32 "Que faudrait-il faire pour contenter des juges si difficiles?" (Racine, Premier Préface. In: Racine, 1962, p. 143).

33 Iphigénie en Aulide (1674) e Phèdre (1677).

34 Esther (1689) e Athalie (1691).

35 Uma das peças de Thomas Corneille, Timocrate (1656), chegou a ser representada oitenta vezes no curso de uma única temporada teatral (Julleville, 1927, p. 176).

36 As primeiras tragédias de Pradon foram Pyrame et Thisbé (1674) e Tamerlan ou la mort de Bajazet (1676).

37 As tragédias mitológicas de La Fosse são Polyxène (1686), Thésée (1700) e Coresus et Calirrhoe (1703).

38 A tradução das Vidas Paralelas foi reeditada em 1595 e em 1603. A obra exerceu grande influência sobre a dramaturgia inglesa, especialmente sobre as tragédias históricas de Shakespeare.

39 A crítica sempre se mostrou um pouco relutante em aceitar Titus Andronicus, tragédia de horror e sensacionalismo, como obra autêntica de Shakespeare. Escrita por volta de 1589 e bastante influenciada pelas tragédias de Sêneca, a peça, conforme Philip Henslowe, foi representada pela primeira vez em 1594. Na edição das obras completas de Shakespeare, realizada sob a responsabilidade de Irving Ribner e George Lyman Kittredge, há referências aos documentos que comprovam a representação da tragédia (The complete works of Shakespeare, 1971, p. 927).

40 O enredo da tragédia foi extraído de contos apócrifos sobre os últimos dias do Império Romano, muito conhecidos na Idade Média. As personagens têm nomes de personalidades romanas, mas os caracteres são criados por Shakespeare.

41 Há uma evidente alusão a Julius Caesar, em Mirror of Martyrs, obra de John Weever, publicada em 1602, e referências à peça feitas por Thomas Platter, viajante suíço que esteve na Inglaterra 
em 1599. Cf. The complete works of Shakespeare, 1971, p. 1006. A. W. Verity (Shakespeare, 1952, p. ix), no entanto, crê que a tragédia tenha sido escrita em 1601.

42 Esse texto de Plutarco é provavelmente baseado em Tito Lívio (II, 40, 1 ss.).

43 Segundo Suetônio e Díon Cássio, Cunobelinus era um governador da Britânia que manteve contatos com Augusto; ao tornar-se rei, em 35 a.C., foi dispensado de pagar tributo a Roma. De acordo com Irving Ribner (The complete works..., s/d, p. 1462), a provável fonte de Cymbeline foi The rare triumph of Love and Fortune, um antigo texto dramático representado diante da rainha Isabel, em Windsor, em 1582, e publicado em 1589.

44 É o caso de Every man in his humour (1598) e Every man out of his humour (1599).

45 Veja-se, por exemplo, Cynthia's revels (1601), Poetaster (1602) e, sobretudo, Volpone (1605).

46 Veja-se, por exemplo, A new way to pay old debts.

47 A esses nomes podemos acrescentar o de Gil Vicente, que, embora português de nascimento, escreveu muitos de seus textos teatrais em espanhol.

48 Vejam-se, por exemplo, sua Comedia de Anfitrión, obra de juventude decalcada sobre o Anfitrião de Plauto, e suas tragédias Venganza de Agamenón e Hécuba triste, traduções, por assim dizer, da Electra de Sófocles e da Hécuba de Eurípides, respectivamente.

49 O teatrólogo se dedica a comédias e entremezes.

50 Jerónimo Bermudez é considerado o primeiro trágico espanhol; suas tragédias Nise lastimosa e Nise laureada se ressentem, porém, da influência da Castro, de Antonio Ferreira.

51 Cristóbal Viruez é autor de Elisa Dido, tragédia mitológica inspirada na Eneida de Virgílio.

\section{REFERÊNCIAS BiBLIOGRÁFICAS}

ALVAREZ, E. \& LOURENÇO, A. A. Historia da Literatura Espanhola. Lisboa: Edições ASA, 1994.

BAYET, J. Littérature latine. Paris: Colin, 1962.

BOLGAR, R. R. The classical heritage and its beneficiaries. Cambridge: Cambridge University Press, 1954.

BRADEN, G. Renaissance tragedy and Senecan tradition: Anger's privilege. New Haven and London: Yale University Press, 1985.

CANO, P. L. \& LORENTE, J. Espectacle, amor i martiris al cinema de Romans. Tarragona: Facultat de Filosofia i Lletres, s/d.

CASALDUERO, J. Estudios sobre el teatro español. 4ª ed. Madrid: Gredos, 1981.

CERVANTES, M. La destruición de Numancia. Ed., introd. y notas de A. HEMENEGILDO. Madrid: Clásicos Castalia, 1994. 
CORNEILLE. Cinna. Notes explicatives, questionnaires, bilans, documents et parcours thématique établis par P. REIX. Paris: Hachette, 1993 (b).

. Horace. Notes explicatives, questionnaires, bilans, documents et parcours thématique établis par E. RICHER. Paris: Hachette, 1993.

FERREIRA, J. Historia da Literatura Portuguesa. Porto: Domingos Barreira, s/d.

HIGHET, G. La tradición clásica. Influencias griegas y romanas en la literatura occidental. México: Fondo de Cultura Económica, 1986.

HUMPHREYS, A. Introduction to Julius Caesar. Oxford: Clarendon Press, 1984.

JULLEVILLE, P. Le théâtre en France. Histoire de la littérature dramatique depuis ses origines jusqu'à nos jours. Nouvelle édition. Paris: Colin, 1927.

LAGARDE, A. \& MICHARD, L. XVI e Siècle. Les grands auteurs français. Paris: Bordas, 1959.

LAGARDE, A. \& MICHARD, L. XVII Siècle. Les grands auteurs français. Paris: Bordas, 1958.

LEGOUIS, É. A short history of English literature. Transl. by V. F. BOYSON e J. COULSON. Oxford: Oxford University Press, 1953.

LUCAS, F. L. Seneca and Elizabethan tragedy. Cambridge: Cambridge University Press, 1922.

MACCALLUM, M. W. Shakespeare's Roman plays and their background. London: MacMillan and Co. Limited, 1935.

MARTINDALE, C \& M. MARTINDALE. Shakespeare and the uses of Antiquity. London and New York: Routledge, 1994.

MIOLA, R. Shakespeare and classical tragedy. Oxford: Clarendon Press, s/d.

RACINE. Oeuvres Complètes. Préface de P. CLARAC, présentation et notes de L. Estang. Paris: Éditions du Seuil, 1962.

SÉNEQUE. Tragédies. Texte ét. et trad. par L. HERRMANN. Paris: Les Belles Lettres, 1971. Vol. I..

SHAKESPEARE, W. Antônio e Cleópatra. Trad. e notas de J. R. O'SHEA. São Paulo: Mandarim, 1997.

. Coriolano/Coriolanus. Trad. de B. HELIODORA. Rio de Janeiro: Nova Fronteira, 1995

. Julius Caesar. Edited by A. W. VERITY. Cambridge: Cambridge University Press, 1952.

. The complete works of Shakespeare. Ed. by I. RIBNER and G. L. KITTREDGE. Walthan, Massachussets/ Toronto: Ginn and Company, 1971. 
SQUAROTTI, G. B. (Org.). Literatura Italiana. Linhas. Problemas. Autores. 2a. ed. São Paulo: Nova Stella/ Inst. Cult. Italo-Brasileiro/ EDUSP, 1989.

TOFFANIN, G. Storia letteraria d'Italia. Il Cinquecento. Milano: Vallardi, 1935.

TRINGALI, D. Horácio poeta da festa: navegar não é preciso. São Paulo: Musas Editora, 1995.

VICINELLI, A. La letteratura d'Italia. Storia e opere di autori. Vol. II. Milano: Vallardi, s/d.

ZORZETTI, N. La pretesta latina e il teatro latino arcaico. Napoli: Liguori Editore, 1980.

\section{INFORME}

O presente trabalho é um recorte de uma pesquisa de maior vulto, intitulada Projeções da pretexta latina no mundo renascentista e barroco, levada a termo com recursos concedidos pelo $\mathrm{CNPq}$, pelos quais reiteramos nossos agradecimentos.

CARDOSO, Z. A. Projections of Latin praetexta during Renaissance and the Baroque Period.

ABSTRACT: As it happened to the ancient tragedy and comedy, which reappeared during Renaissance and the Baroque Period, the historical drama having a Roman subject - heir of Latin praetexta - was then also explored by playwrights. In Italy, France, England and Spain, in the $16^{\text {th }}$ and $17^{\text {th }}$ centuries, a lot of plays about Roman history started arising. They were very successful and in a certain way prepared the development of the "Roman" novel and of the peplum - the motion picture which emphasized fact determining the importance of The Eternal City.

KEY WORDS: Renaissance; Baroque Period; historical drama; praetexta; peplum. 